\title{
Author Correction: Tropical explosive volcanic eruptions can trigger El Niño by cooling tropical Africa
}

\author{
Myriam Khodri (10 1, Takeshi Izumo (10) 1,2, Jérôme Vialard (10 1, Serge Janicot (10 1, Christophe Cassou ${ }^{3}$,

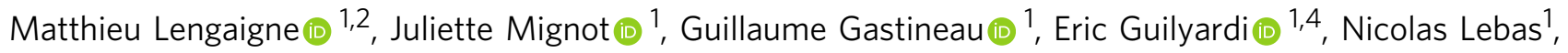 \\ Alan Robock (iD ${ }^{5}$ \& Michael J. McPhaden 6
}

Correction to: Nature Communications https://doi.org/10.1038/s41467-017-00755-6, published online 03 October 2017

The original version of this Article omitted a reference to previous work in 'Mann, M.E., Cane, M.A., Zebiak, S.E., Clement, A., Volcanic and Solar Forcing of the Tropical Pacific Over the Past 1000 Years, J. Climate 18, 447-456 (2005)'. This has been added as reference 62 at the end of the fourth sentence of the fourth paragraph of the Introduction: 'Early studies using simple coupled ocean-atmosphere models ${ }^{26}$ proposed that following volcano-induced surface cooling, upwelling in the eastern equatorial Pacific acting on a reduced vertical temperature contrast between the ocean surface and interior leads to anomalous warming in this region, thereby favouring El Niño development the following year ${ }^{12,27,62}$.' This has been corrected in the PDF and HTML versions of the Article.

Published online: 22 February 2018

\begin{abstract}
(c) (i)
Open Access This article is licensed under a Creative Commons Attribution 4.0 International License, which permits use, sharing, adaptation, distribution and reproduction in any medium or format, as long as you give appropriate credit to the original author(s) and the source, provide a link to the Creative Commons license, and indicate if changes were made. The images or other third party material in this article are included in the article's Creative Commons license, unless indicated otherwise in a credit line to the material. If material is not included in the article's Creative Commons license and your intended use is not permitted by statutory regulation or exceeds the permitted use, you will need to obtain permission directly from the copyright holder. To view a copy of this license, visit http://creativecommons.org/licenses/by/4.0/.
\end{abstract}

(C) The Author(s) 2018

\footnotetext{
${ }^{1}$ Laboratoire d'Océanographie et du Climat: Expérimentations et approches numériques, Sorbonne Universités, UPMC Université Paris 06, IPSL, UMR CNRS/ IRD/MNHN, F-75005 Paris, France. ${ }^{2}$ Indo-French Cell for Water Sciences, IISc-NIO-IITM-IRD Joint International Laboratory, NIO, 403002 Goa, India. ${ }^{3} \mathrm{CECl}, \mathrm{CNRS}$, Cerfacs, Université de Toulouse, 31057 Toulouse, France. ${ }^{4}$ NCAS-Climate, University of Reading, RG6 6BB Reading, UK. 5 Department of Environmental Sciences, Rutgers University, New Brunswick, NJ 08901, USA. 6 Pacific Marine Environmental Laboratory (PMEL), NOAA, Seattle, WA 98115, USA. Correspondence and requests for materials should be addressed to M.K. (email: myriam.khodri@locean-ipsl.upmc.fr)
} 